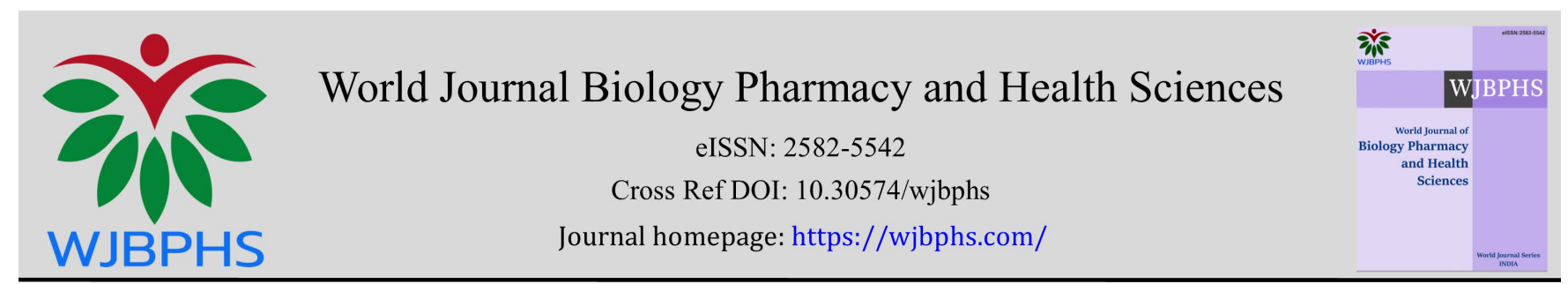

(RESEARCh ARTicle)

\title{
Association between malnutrition and some water, sanitation and hygiene (WASH) factors among school children in Gombe State, Nigeria
}

\author{
Mela Danjin ${ }^{1,}{ }^{*}$, Henry 0. Sawyerr ${ }^{1}$ and Solomon O. Adewoye ${ }^{2}$ \\ ${ }^{1}$ Department of Environmental Health Science, School of Allied Health and Environmental Science, Kwara State \\ University, Malete, Nigeria. \\ 2 Pure and Applied Biology (Environmental Biology Unit), Faculty of Pure and Applied Sciences, Ladoke Akintola \\ University of Technology (LAUTECH), Ogbomoso, Oyo State, Nigeria
}

World Journal of Biology Pharmacy and Health Sciences, 2021, 05(01), 055-065

Publication history: Received on 12 January 2021; revised on 20 January 2021; accepted on 22 January 2021

Article DOI: https://doi.org/10.30574/wjbphs.2021.5.1.0006

\begin{abstract}
The state of the environment in which we live and certain hygienic practices we indulge in has been known to affect our nutritional status. This study was aimed at examining the association between malnutrition and some selected water, sanitation and hygiene (WASH) practices among school children in Gombe State Nigeria. A cross sectional survey was conducted between March and June, 2019. A total of 745 pupils were selected from 12 public and 6 private schools across 6 LGAs in Gombe state, using multi-stage sampling technique. Anthropometric measurements of heights and weights of the study participants were done using standard instruments and procedures. Other relevant data (age, sex, some environmental variables etc) were collected using a structured template. Data analysis was done using IBM SPSS version 21 and key variables were presented using descriptive statistics, while associations were tested using Chi square. Odd ratio (OR) was used to estimate risks of malnutrition among the subjects and p-value was set at 0.05 . The pupils had a mean age of $9.96 \pm 2.26$ years, $50.9 \%$ of whom were males the rest being females. Though $84.6 \%$ of them had toilets in their residences not all of them (98.6\%) put them to use. A good proportion (79.1\%) dispose their refuse by dumping and slightly more than half of them (51.7\%) have access to pipe borne water. And though only two (method of refuse disposal and source of drinking water) out of the eight WASH variables studied were found to be associated with underweight (Composite indicator of malnutrition), all the eight variables were found to be associated with stunting (chronic malnutrition). Overall, $20.8 \%$ and $22.4 \%$ of the subjects were underweight and stunted, respectively. The foregoing raises a germane concern about the role of WASH in malnutrition among school children and the need for a comprehensive and sustainable school feeding programme in the state and country at large. There should also be an integration of a WASH component in all nutrition intervention programmes.
\end{abstract}

Keywords: Malnutrition; Underweight; Stunting; WASH; Association; School Children

\section{Introduction}

Globally, about 52 Million (8\%) of children under-five (U5) are wasted, and 155 Million (23\%) stunted [1]. An estimate of 9.6 Million U5 children are stunted and wasted in Africa and under-nutrition explains around $45 \%$ of deaths among U5 children [2]. The most recent demographic and health survey reveals that in Nigeria 37\% of children U5 are stunted, $7 \%$ wasted and 22\% underweight [3]. According to the survey in north eastern (NE) Nigeria $49.1 \%$ U5 children are stunted, 9.7\% wasted and 29.9\% underweight while in Gombe State 51.2\% U5 children are stunted, 7.8\% wasted and $30.4 \%$ underweight. These childhood nutritional problems later tends to reflect negatively on the school age child and adolescent's nutritional status [4]. An estimated 2.3 billion people lack basic sanitation service and about 892 million

\footnotetext{
${ }^{*}$ Corresponding author: Mela Danjin

Department of Environmental Health Science, School of Allied Health and Environmental Science, Kwara State University, Malete, Nigeria.
}

Copyright $(2021$ Author(s) retain the copyright of this article. This article is published under the terms of the Creative Commons Attribution Liscense 4.0. 
people practice open defecation worldwide, while an estimated 844 million people do not have access to improved water sources [5]. The situation is worst in Sub-Saharan Africa and the developing countries. In Nigeria only 64.2\%, in the NE 52.4\% and in Gombe State 39.4\% people have access to improved water sources [6]. Again in Nigeria only 51.6\%, in the NE $49.3 \%$ and in Gombe State $46.7 \%$ of people have access to improved sanitation [6].

One-third of all undernourished children worldwide reside in Sub-Saharan Africa (SSA) [7]. Nigeria is experiencing significant challenges to provide access to improved Water, sanitation, and hygiene (WASH) to the population [8]. And about $56 \%$ of malnutrition is associated with inadequate WASH [9]. Poor state of WASH help in the spread of infectious diseases and intestinal worms (nematode infection), diarrhea etc. [4, 10,11]. Diarrhoea can be considered as a cause and consequence of malnutrition. The foregoing encourage the development of environmental enteric dysfunction (EED) or environmental enteropathy (EE) [4]. EE is an inflammatory condition of the gut of children which is characterized by villous atrophy and malabsorption of digested food thereby causing under-nutrition. Some of the negative impacts of chronic malnutrition (stunting) in early life include high mortality, decreased cognitive development, poor school performance, and reduced productivity in adults [9]. However, more research is needed to confirm the relationship between malnutrition and WASH [12].

Some of the negative impacts of chronic malnutrition (stunting) in early life include high mortality, decreased cognitive development, poor school performance, and reduced productivity in adults [9].The increase in child under-nutrition with age could be as a result of increased interaction of the older children with the environment which may lead to increased exposure to childhood diseases either through consumption of contaminated foods, drinking water from unimproved sources or poor environmental sanitation [7]. And in view of the fact that one-third of all undernourished children worldwide reside in Sub-Saharan Africa (SSA), this study sought to assess the association between malnutrition (underweight and stunting) and water sanitation and hygiene (WASH) practices among school children in Gombe State, Nigeria.

\section{Material and methods}

\subsection{Study Area}

This study was conducted in Gombe State, north eastern Nigeria. The state is located between latitudes $90^{\circ} 30^{\prime}$ and $12^{\circ} 30^{\prime} \mathrm{N}$, longitudes $8^{\circ} 45^{\prime}$ and $11^{\circ} 45^{\prime}$ E. Some other Nigerian states that share borders with Gombe State include: Yobe state to the north, Bauchi state to the west, Taraba State to the south while Borno and Adamawa states are neighbouring states to the east. Gombe state is made up of eleven local government areas (LGAs) that form three geo-political districts - northern, central and southern senatorial districts. A total of eighteen (18) primary schools scattered across the six LGAs were involved in this study. As at the year 2017 Gombe State had an estimated projected population of 3,256,962 and a landmass area of 20,265 square kilometers [13].

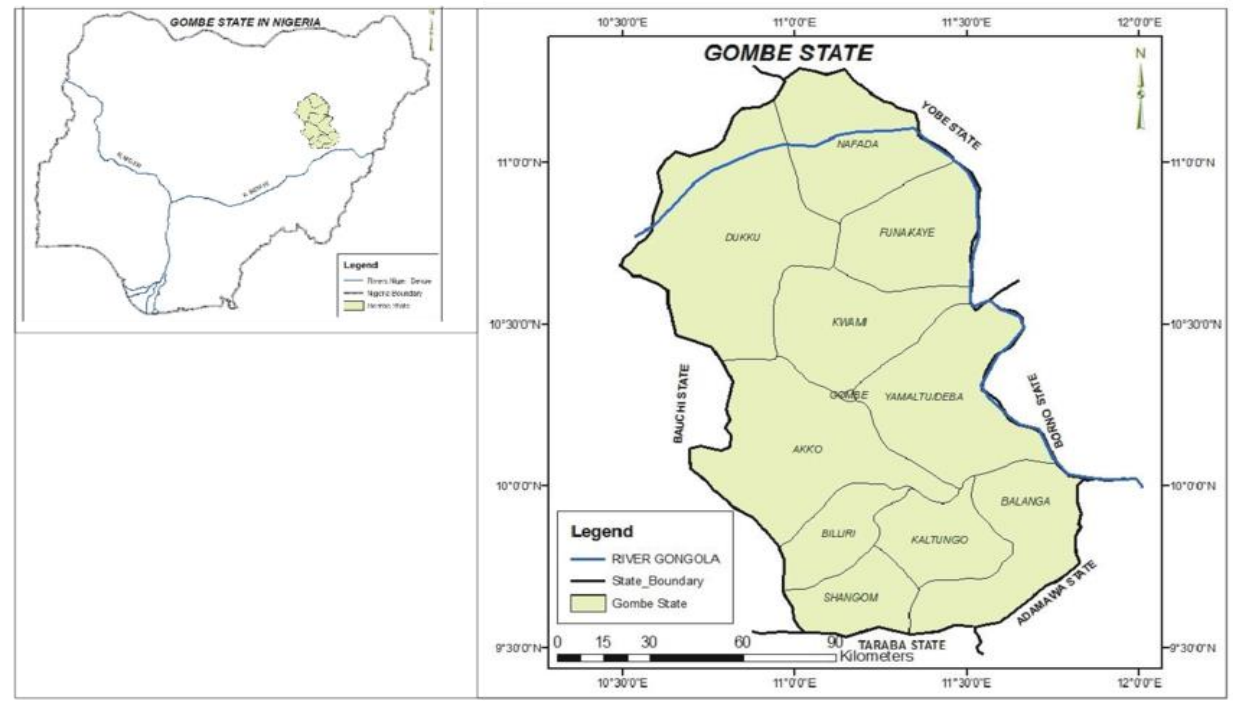

Figure 1 Map of Gombe State 


\subsection{Target Population and Population of the study}

The target population for this study comprised all children enrolled in all public and private primary schools of Gombe State. As at the time of data collection a total of 492, 962 pupils were enrolled in 1, 914 Primary Schools in Gombe state [14]. This figure can be disaggregated into one thousand three hundred and fourty one $(1,341)$ public and five hundred and seventy three (573) private primary schools in Gombe State. On the other hand the population of study consist of all school children in the 18 public and private primary schools selected from the urban and rural areas of Gombe state (see Fig. 1).

\subsection{Study Design}

This study was a descriptive cross sectional survey.

\subsection{Eligibility Criteria}

All school children within the age group of 6 - 15 years who were enrolled in the selected primary schools in Gombe State and all those who were present in the schools at the time of the survey were eligible. Also eligible were school children who may have stayed in the state for at least a year.

\subsection{Study Participants}

The study participants were selected primary school pupils aged 6-15 in Gombe state.

\subsection{Sample Size Determination}

The sample size for this study was determined using the sample size formula for comparing two proportions [15].

$\mathrm{n}=[P 1(1-P 1)+P 2(1-P 2)](Z \alpha / 2+Z \beta) 2 /(P 1-P 2) 2$

Where:

n: required sample size

$P 1$ : estimated proportion for malnutrition in urban areas (about 12\%) [6]

P2: estimated proportion for malnutrition and malaria in rural areas (comparison group) in the North East (about 36\%) [6]

$\alpha$ : level of statistical significance

$\mathrm{Z} \alpha / 2$ : Represents the desired level of statistical significance (usually 1.96 for $\alpha=0.05$ )

$\mathrm{Z} \beta$ : Represents the desired power (estimated to be 0.84 for $80 \%$ power)

n for each group $* 2=$ total sample (i.e. for the 2 groups)

The calculations ensured that the minimum detectable difference in malnutrition among the school children in rural and urban areas, or in public and private schools; was $10 \%$.

The calculated minimum sample size for the study was 295 pupils from urban schools and 295 from rural schools. Put together a minimum sample size of 590 was determined. However, this was adjusted upwards to a final sample size of 745 .

\subsection{Sampling Technique}

Multistage sampling technique was employed to select the subjects for this study. The total number of Primary schools in Gombe state was estimated at 1, 914. This comprised 573 private and 1, 341 public primary schools [14], implying that the ratio of private to public schools was 1:2.3. Hence, 6 private and 12 public primary schools were purposively selected from both urban and rural areas of the state. From the selected schools a sample of 745 children were selected in stages. Firstly, two LGAs were selected from each senatorial district using simple balloting. In the second stage three primary schools - a public primary school from a rural area and a public and a private school from an urban or a suburban area - were selected per LGA. This added up to a total of 18 schools that were selected. In each primary school 
(stage three) four classes were conveniently selected from among any of primary one to primary six. In the final stage (stage four), at least 10 subjects were systematically picked from each of the 4 classes (40). At any stage the subjects were free to drop out of the study.

\subsection{Ethical approval}

An ethical approval and clearance for this study was obtained from the Gombe State Ministry of Health Research and Ethics Committee (GSMoHREC) - Ref: MoH/ADM/S/658. In addition, consents of the heads of the 18 schools that participated in the study, the parents and the volunteering pupils were all secured before conducting the study on the children. The study was conducted in tandem with the Helsinki Declaration.

\subsection{Data Collection}

Face-to-face interview and anthropometric measurements for malnutrition were used for the data collection. And the exercise was conducted between March and June, 2019.

\subsubsection{Face to face Interview}

A face-to-face oral interview was first conducted with each of the subjects to collect socio-demographic and other information related to malnutrition using a validated questionnaire/data collection template.

\subsubsection{Anthropometric Measurements for Malnutrition}

Anthropometric measurements were then carried out on all the subjects using standard procedures as described by Jelliffe [16]. The instruments used include: portable wall measuring rod (stadiometre), calibrated in centimeters for measurement of height; HANA bathroom weighing scale with readings taken to the nearest $0.5 \mathrm{~kg}$. To validate the instrument and ensure reliability, a pilot study was carried out in one of the public primary schools not selected for the main study using the same instruments and procedures that were later used during the main data collection exercise.

\subsection{Data Management and Analysis}

Out of a total of 748 instruments retrieved, 745 were assessed and found be complete and usable. Data analysis was done using IBM Statistical Package for Social Sciences (SPSS) version 21 (SPSS Inc. Chicago, IL, USA). Both descriptive and inferential statistics were used to summarize and make inferences on the data. Chi square $\left(\chi^{2}\right)$ and odd ratio (OR) were computed and used to compare proportions and estimate risks of malnutrition among the subjects. Findings were considered significant at P-values less than 0.05. Data were presented in tables. The indicators of children's nutritional status that were used for this study included stunting and underweight which were obtained from anthropometric measurements (height and weight) and their corresponding ages from oral interview. Height for age z-score (HAZ), weight for age z-score (WAZ) and weight for height z-score (WHZ) were calculated WHO AnthroPlus software [17].

\section{Results and discussion}

\subsection{Background (Demographic and WASH) information about the Participants}

Findings from this survey shows that study participants had a mean age of $9.96 \pm 2.26$ years and an average family size of $7.47 \pm 2.425$ persons (Table 1). The school children studied fall within a mean birth order of $3.37 \pm 2.325$ and about half $(50.9 \%)$ of them were males and the rest (49.1\%) were females (Table 1 ). Though toilets were available in $86.4 \%$ of pupils' households, not all (98.6\%) make use of them (Table 2). Some (18.0\%) of the respondents use shared toilet with neighbours. These figures are way far higher than the national figures where only $56 \%$ of Nigerian households use improved toilet facilities [18]. The finding is also higher than another finding from Ibadan, south west Nigeria where the use of improved latrine was put at 54\% [19]. A proportion (12.4\%) of the respondents stay in rented houses as another good majority (79.1\%) admitted practicing open dumping as a method of waste disposal. Again, this is higher than those from the study in Ibadan - 41.2\% [19]. Only about a half (51.7\%) of the respondents had access to improved (Pipe borne water) source of drinking water. This finding is slightly higher than the one reported in the most recent national demographic and health survey conducted in 2018, which is $43 \%$ for Gombe state [18]. Contrarily, the overall national average of $66 \%$ households that have access to an improved source of drinking water (74\% in urban areas and $58 \%$ in rural areas) is higher than the reported in this study [18]. Almost half (48.5\%) of the children stay in houses that have drainage or that are not water-logged, while $53.3 \%$ of them stay in cement/bricks houses. 


\subsection{Association between Malnutrition and Some WASH Factors}

Several studies in Nigeria and elsewhere have demonstrated strong association between the different forms of malnutrition and some environmental and WASH factors [7-12, 20, 21].

\subsubsection{Underweight (Malnutrition) and WASH Factors}

The findings of this study seems to suggest that availability of toilet in residence, toilet being put to use, using shared toilet with neighbours, and type of residential facility appear not to be associated $(\mathrm{P}=<0.05)$ with underweight (Table 3). However, children from households practicing open dumping as a means/method of waste disposal recorded the highest prevalence of underweight (22.8\%) at $\chi 2=10.673$ and $\mathrm{P}=0.005$. And children from households who had access to improved source of drinking water recorded significantly low burden of underweight (compared to those from households with unimproved i.e. Pipe borne water: $17.4 \%$ vs. well water: $26.9 \%, \chi 2=10.997$, $\mathrm{P}=0.012$ ). This findings are consistent with findings from Tanzania by Mshida et al [22], and from Onitsa South eastern Nigeria by Ndukwu et al [23]. The pathophysiology of undernutrition due to prolong influence of unhygienic environmental factors via environmental enteropathy (EE) or Environmental Enteric Dysfunction (EED) and which triggers mal-absorption has been adequately described [12, 24-26]. This aptly explains the association between underweight and the WASH factors.

\subsubsection{Stunting (Malnutrition) and WASH Factors}

This study also demonstrates the existence of an association between stunting and water sanitation and hygiene (WASH) indicators (Table 4). Children from households without toilets (33.7\%) were about twice at risk of being stunted than those from households with toilets $(\chi 2=8.447, \mathrm{P}=0.004, \mathrm{OR}=1.946, \mathrm{CI}=1.235-3.066)$. Children from households not using their toilets were also about twice more at risk of stunting than those from households putting their toilets to use $(33.6 \%)$ to use $(\chi 2=9.003, P=0.003,0 R=1.958, C I=1.255-3.055)$. Furthermore, children from households that don't take advantage of using a shared toilet (24.3\%) were also more (twice) at risk of stunting than those that do $(\chi 2=6.269, \mathrm{df}=1, \mathrm{OR}=1.926, \mathrm{CI}=1.145-3.239)$. Children that resided in houses owned by parents/guardians had high prevalence (23.5\%) stunting than those in rented apartments $(\chi 2=4.054, \mathrm{P}=0.044$, $\mathrm{OR}=0.537, \mathrm{CI}=0.290-0.992)$. Children from households that disposed waste at dump sites carried the highest burden $(24.5 \%)$ of stunting than those from households that disposed their waste more properly $(\chi 2=8.499, \mathrm{P}=0.014)$. Children from households with improved source of drinking water (portable/pipe borne water) had low prevalence $(15.3 \%)$ of drinking stunting $(\chi 2=23.473, \mathrm{p}=0.000)$. This consistent association and link between stunting and negative WASH practices or factors are in tandem with several other studies [7, 12, 22, 23, 27]. And this could be due to the fact that compromised WASH factors could predispose to diseases which in themselves are among the immediate causes of malnutrition [28]. In another breath, poor state of WASH facilities could be indicators of poor socioeconomic status that could be potent drivers of inadequate dietary intake and consequently manifesting in malnutrition (stunting as an indicator of long term deprivation).

Table 1 Some socio-demographic information of study subjects

\begin{tabular}{|l|l|l|l|l|}
\hline Variable & Frequency (n) & Mean \pm Std. Dev./\% & Min & Max \\
\hline Age of Child & 745 & $9.96 \pm 2.26$ & 6 & 15 \\
\hline Family Size & 739 & $7.47 \pm 2.43$ & 1 & 15 \\
\hline Birth Order & 745 & $3.37 \pm 2.33$ & 1 & 13 \\
\hline Sex & & & & \\
\hline Male & 379 & 50.9 & & - \\
\hline Female & 366 & 49.1 & - & - \\
\hline Total & 745 & 100.0 & - & - \\
\hline
\end{tabular}


Table 2 Environmental factors (WASH Indicators) around the school children

\begin{tabular}{|c|c|c|c|}
\hline $\mathbf{S} / \mathbf{N}$ & Variable/Category & Frequency & Percentage \\
\hline \multirow[t]{4}{*}{1} & Availability of toilet in residence & & \\
\hline & No & 101 & 13.6 \\
\hline & Yes & 643 & 86.4 \\
\hline & Total & 744 & 100.0 \\
\hline \multirow[t]{4}{*}{2} & Toilet being put to use & & \\
\hline & No & 9 & 1.4 \\
\hline & Yes & 634 & 98.6 \\
\hline & Total & 643 & 100.0 \\
\hline \multirow[t]{4}{*}{3} & Uses shared toilet with neighbours & & \\
\hline & No & 605 & 82.0 \\
\hline & Yes & 133 & 18.0 \\
\hline & Total & 738 & 100.0 \\
\hline \multirow[t]{4}{*}{4} & Type of residential facility & & \\
\hline & Rented & 92 & 12.4 \\
\hline & Owned by parent or guardian & 652 & 87.6 \\
\hline & Total & 744 & 100.0 \\
\hline \multirow[t]{7}{*}{5} & Method of refuse disposal & & \\
\hline & Dumping & 587 & 79.1 \\
\hline & Burning & 74 & 10.0 \\
\hline & Burying & 3 & 0.4 \\
\hline & Refuse collectors & 67 & 9.0 \\
\hline & Dumping + Burning & 11 & 1.5 \\
\hline & Total & 742 & 100.0 \\
\hline \multirow[t]{6}{*}{6} & Source of drinking water & & \\
\hline & Stream/river & 60 & 8.1 \\
\hline & Well & 108 & 14.5 \\
\hline & Water vendors/Truck pushers/Tanks & 192 & 25.8 \\
\hline & Pipe borne water & 385 & 51.7 \\
\hline & Total & 745 & 100.0 \\
\hline \multirow[t]{4}{*}{7} & House environment has drainage/ not & & \\
\hline & No & 384 & 51.5 \\
\hline & Yes & 361 & 48.5 \\
\hline & Total & 745 & 100.0 \\
\hline \multirow[t]{4}{*}{8} & Type of residential housing material & & \\
\hline & Cement/Brick & 397 & 53.3 \\
\hline & Mud, cornstalk etc & 348 & 46.7 \\
\hline & Total & 745 & 100.0 \\
\hline
\end{tabular}


Table 3 Association between malnutrition (underweight) and WASH Indicators

\begin{tabular}{|c|c|c|c|c|c|c|c|c|}
\hline \multirow[t]{2}{*}{ SN } & \multirow[t]{2}{*}{ Variable } & \multicolumn{2}{|c|}{$\begin{array}{l}\text { Malnutrition } \\
\text { (Underweight) }\end{array}$} & \multirow[t]{2}{*}{ OR } & \multirow[t]{2}{*}{ CI } & \multirow[t]{2}{*}{$\begin{array}{l}\text { Chi } \\
\text { Sq }\end{array}$} & \multirow[t]{2}{*}{ df } & \multirow[t]{2}{*}{$\begin{array}{l}\text { F-Exact/ } \\
\text { P-Value }\end{array}$} \\
\hline & & Yes $(<-2)$ & No $(-2+)$ & & & & & \\
\hline & & $\mathrm{n}(\%)$ & $\mathrm{n}(\%)$ & & & & & \\
\hline \multirow[t]{4}{*}{1} & \multicolumn{8}{|l|}{ Availability of toilet in residence } \\
\hline & No & $\begin{array}{l}17 \\
(16.8 \%)\end{array}$ & $84(83.2 \%)$ & & & & & \\
\hline & Yes & $\begin{array}{l}138 \\
(21.5 \%)\end{array}$ & $\begin{array}{l}505 \\
(78.5 \%)\end{array}$ & & & & & \\
\hline & Total & $\begin{array}{l}155 \\
(20.8 \%)\end{array}$ & $\begin{array}{l}589 \\
(79.2 \%)\end{array}$ & $\begin{array}{l}0.74 \\
1\end{array}$ & $\begin{array}{l}(0.425- \\
1.289)\end{array}$ & 1.135 & 1 & $\begin{array}{l}0.287 / 0.3 \\
56\end{array}$ \\
\hline \multirow[t]{4}{*}{2} & \multicolumn{8}{|l|}{ Toilet being put to use } \\
\hline & No & $1(11.1 \%)$ & $8(88.9 \%)$ & & & & & \\
\hline & Yes & $\begin{array}{l}137 \\
(21.6 \%)\end{array}$ & $\begin{array}{l}497 \\
(78.4 \%)\end{array}$ & & & & & \\
\hline & Total & $\begin{array}{l}138 \\
(21.5 \%)\end{array}$ & $\begin{array}{l}505 \\
(78.5 \%)\end{array}$ & $\begin{array}{l}0.45 \\
3\end{array}$ & $\begin{array}{l}(0.056- \\
3.657)\end{array}$ & 0.58 & 1 & $\begin{array}{l}0.446 / 0.6 \\
92\end{array}$ \\
\hline \multirow[t]{4}{*}{3} & \multicolumn{8}{|l|}{ Uses shared toilet with neighbours } \\
\hline & No & $\begin{array}{l}130 \\
(21.5 \%)\end{array}$ & $\begin{array}{l}475 \\
(78.5 \%)\end{array}$ & & & & & \\
\hline & Yes & $\begin{array}{l}25 \\
(18.8 \%)\end{array}$ & $\begin{array}{l}108 \\
(81.2 \%)\end{array}$ & & & & & \\
\hline & Total & $\begin{array}{l}155 \\
(21.0 \%)\end{array}$ & $\begin{array}{l}583 \\
(79.0 \%)\end{array}$ & $\begin{array}{l}1.18 \\
2\end{array}$ & $\begin{array}{l}(0.734- \\
1.904)\end{array}$ & 0.476 & 1 & $\begin{array}{l}0.490 / 0.5 \\
57\end{array}$ \\
\hline \multirow[t]{4}{*}{4} & \multicolumn{8}{|l|}{ Type of residential facility } \\
\hline & Rented & $\begin{array}{l}19 \\
(20.7 \%)\end{array}$ & $73(79.3 \%)$ & & & & & \\
\hline & Owned by parent/guardian & $\begin{array}{l}135 \\
(20.7 \%)\end{array}$ & $\begin{array}{l}517 \\
(79.3 \% 0\end{array}$ & & & & & \\
\hline & Total & $\begin{array}{l}154 \\
(20.7 \%)\end{array}$ & $\begin{array}{l}590 \\
(79.3 \%)\end{array}$ & $\begin{array}{l}0.99 \\
7\end{array}$ & $\begin{array}{l}(0.581- \\
1.709)\end{array}$ & 0 & 1 & $\begin{array}{l}0.991 / 1.0 \\
00\end{array}$ \\
\hline \multirow[t]{5}{*}{5} & \multicolumn{8}{|l|}{ Method of refuse disposal } \\
\hline & Dumping & $\begin{array}{l}134 \\
(22.8 \%)\end{array}$ & $\begin{array}{l}453 \\
(77.2 \%)\end{array}$ & $\begin{array}{l}3.42 \\
3\end{array}$ & $\begin{array}{l}(1.544- \\
7.586)\end{array}$ & & & \\
\hline & $\begin{array}{l}\text { Dumping and Burning or } \\
\text { burying }\end{array}$ & $7(8.0 \%)$ & $81(92.0 \%)$ & - & & & & \\
\hline & Refuse collection & $\begin{array}{l}12 \\
(17.9 \%)\end{array}$ & $55(82.1 \%)$ & $\begin{array}{l}1.89 \\
0\end{array}$ & $\begin{array}{l}(1.130- \\
3.162)\end{array}$ & & & \\
\hline & Total & $\begin{array}{l}153 \\
(20.6 \%)\end{array}$ & $\begin{array}{l}589 \\
(79.4 \%)\end{array}$ & & & $\begin{array}{l}10.67 \\
3\end{array}$ & 2 & $0.005^{*}$ \\
\hline \multirow[t]{2}{*}{6} & \multicolumn{8}{|l|}{ Source of drinking water } \\
\hline & Stream/river & $8(13.3 \%)$ & $52(86.7 \%)$ & $\begin{array}{l}0.73 \\
0\end{array}$ & $\begin{array}{l}(0.332- \\
1.608)\end{array}$ & & & \\
\hline
\end{tabular}




\begin{tabular}{|c|c|c|c|c|c|c|c|c|}
\hline & Well & $\begin{array}{l}29 \\
(26.9 \%)\end{array}$ & $79(73.1 \%)$ & $2^{1.74}$ & $\begin{array}{l}(1.056- \\
2.874)\end{array}$ & & & \\
\hline & $\begin{array}{l}\text { Water vendors/Truck } \\
\text { pushers/Tanks }\end{array}$ & $\begin{array}{l}51 \\
(26.6 \%)\end{array}$ & $\begin{array}{l}141 \\
(73.4 \%)\end{array}$ & $\begin{array}{l}1.71 \\
7\end{array}$ & $\begin{array}{l}(1.134- \\
2.599)\end{array}$ & & & \\
\hline & Pipe borne water & $\begin{array}{l}67 \\
(17.4 \%)\end{array}$ & $\begin{array}{l}318 \\
(82.6 \%)\end{array}$ & - & & & & \\
\hline & Total & $\begin{array}{l}155 \\
(20.8 \%)\end{array}$ & $\begin{array}{l}590 \\
(79.2 \%)\end{array}$ & & & $\begin{array}{l}10.99 \\
7\end{array}$ & 3 & $0.012^{*}$ \\
\hline 7 & \multicolumn{8}{|c|}{ Environment has drainage/ not water-logged } \\
\hline & No & $\begin{array}{l}73 \\
(19.0 \%)\end{array}$ & $\begin{array}{l}311 \\
(81.0 \%)\end{array}$ & & & & & \\
\hline & Yes & $\begin{array}{l}82 \\
(22.7 \%)\end{array}$ & $\begin{array}{l}279 \\
(77.3 \%)\end{array}$ & & & & & \\
\hline & Total & $\begin{array}{l}155 \\
(20.8 \%)\end{array}$ & $\begin{array}{l}590 \\
(79.2 \%)\end{array}$ & $\begin{array}{l}0.79 \\
9\end{array}$ & $\begin{array}{l}(0.560 \\
1.138)\end{array}$ & 1.550 & 1 & 0.213 \\
\hline 8 & \multicolumn{8}{|c|}{ Type of residential housing material } \\
\hline & Cement/Brick & $\begin{array}{l}73 \\
(18.4 \%)\end{array}$ & $\begin{array}{l}324 \\
(81.6 \%)\end{array}$ & & & & & \\
\hline & Mud, cornstalk etc & $\begin{array}{l}82 \\
(23.6 \%)\end{array}$ & $\begin{array}{l}266 \\
(76.4 \%)\end{array}$ & & & & & \\
\hline & Total & $\begin{array}{l}155 \\
(20.8 \%)\end{array}$ & $\begin{array}{l}590 \\
(79.2 \%)\end{array}$ & $\begin{array}{l}0.79 \\
9\end{array}$ & $\begin{array}{l}(0.513- \\
1.042)\end{array}$ & 3.014 & 1 & 0.083 \\
\hline
\end{tabular}

Table 4 Association between malnutrition (Stunting) and WASH Indicators

\begin{tabular}{|c|c|c|c|c|c|c|c|c|}
\hline \multirow[t]{2}{*}{ SN } & \multirow[t]{2}{*}{ Variable/ Category } & \multicolumn{2}{|c|}{ Malnutrition (Stunting) } & \multirow[t]{2}{*}{ OR } & \multirow[t]{2}{*}{ CI } & \multirow[t]{2}{*}{ Chi Sq } & \multirow[t]{2}{*}{ df } & \multirow[t]{2}{*}{ P-Value } \\
\hline & & Yes $(<-2)$ & No $(-2+)$ & & & & & \\
\hline & & $\mathrm{n}(\%)$ & $\mathrm{n}(\%)$ & & & & & \\
\hline \multirow[t]{4}{*}{1} & \multicolumn{8}{|c|}{ Availability of toilet in residence } \\
\hline & No & $34(33.7 \%)$ & $67(66.3 \%)$ & & & & & \\
\hline & Yes & $133(20.7 \%)$ & $510(79.3 \%)$ & & & & & \\
\hline & Total & $167(22.4 \%)$ & $577(77.6 \%)$ & 1.946 & $\begin{array}{l}(1.235- \\
3.066)\end{array}$ & 8.447 & 1 & $0.007^{*}$ \\
\hline \multirow[t]{4}{*}{2} & \multicolumn{8}{|l|}{ Toilet being put to use } \\
\hline & No & $36(33.6 \%)$ & $71(66.4 \%)$ & & & & & \\
\hline & Yes & $131(20.6 \%)$ & $506(79.4 \%)$ & & & & & \\
\hline & Total & $167(22.4 \%)$ & $577(77.6 \%)$ & 1.958 & $\begin{array}{l}(1.255- \\
3.055)\end{array}$ & 9.003 & 1 & $0.004^{*}$ \\
\hline \multirow[t]{3}{*}{3} & \multicolumn{8}{|c|}{ Uses shared toilet with neighbours } \\
\hline & No & $147(24.3 \%)$ & $458(75.7 \%)$ & & & & & \\
\hline & Yes & $19(14.3 \%)$ & $114(85.7 \%)$ & & & & & \\
\hline
\end{tabular}


World Journal of Biology Pharmacy and Health Sciences, 2021, 05(01), 055-065

\begin{tabular}{|c|c|c|c|c|c|c|c|c|}
\hline & Total & $166(22.5 \%)$ & $572(77.5 \%)$ & 1.926 & $\begin{array}{l}(1.145- \\
3.239)\end{array}$ & 6.269 & 1 & $0.012 *$ \\
\hline \multirow[t]{4}{*}{4} & \multicolumn{8}{|c|}{ Type of residential facility } \\
\hline & Rented & $13(14.1 \%)$ & $79(85.9 \%)$ & & & & & \\
\hline & $\begin{array}{l}\text { Owned by parent/ } \\
\text { guardian }\end{array}$ & $153(23.5 \%)$ & $499(76.5 \%)$ & & & & & \\
\hline & Total & $166(22.3 \%)$ & $578(77.7 \%)$ & 0.537 & $\begin{array}{l}(0.290- \\
0.992)\end{array}$ & 4.054 & 1 & $0.045^{*}$ \\
\hline \multirow[t]{5}{*}{5} & \multicolumn{8}{|c|}{ Method of refuse disposal } \\
\hline & Dumping & $144(24.5 \%)$ & $443(75.5 \%)$ & 2.786 & $\begin{array}{l}(1.246- \\
6.233)\end{array}$ & & & \\
\hline & $\begin{array}{l}\text { Dumping and } \\
\text { Burning or burying }\end{array}$ & $15(17.0 \%)$ & $73(83.0 \%)$ & 1.761 & $\begin{array}{l}(0.674- \\
4.600)\end{array}$ & & & \\
\hline & Refuse collectors & $7(10.4 \%)$ & $60(89.6 \%)$ & - & & & & \\
\hline & Total & $166(22.4 \%)$ & $576(77.6 \%)$ & & & 8.499 & 2 & $0.014^{*}$ \\
\hline \multirow[t]{6}{*}{6} & \multicolumn{8}{|c|}{ Source of drinking water } \\
\hline & Stream/river & $19(31.7 \%)$ & $41(68.3 \%)$ & 2.561 & $\begin{array}{l}(1.391- \\
4.715)\end{array}$ & & & \\
\hline & Well & $34(31.5 \%)$ & $74(68.5 \%)$ & 2.539 & $\begin{array}{l}(1.553- \\
4.151)\end{array}$ & & & \\
\hline & $\begin{array}{l}\text { Water } \\
\text { vendors/Truck } \\
\text { pushers/Tanks }\end{array}$ & $55(28.6 \%)$ & 137 (71.4\%) & 2.218 & $\begin{array}{l}(1.460- \\
3.370)\end{array}$ & & & \\
\hline & Pipe borne water & $59(15.3 \%)$ & $326(84.7 \%)$ & - & & & & \\
\hline & Total & $167(22.4 \%)$ & $578(77.6 \%)$ & & & 23.473 & 3 & $0.000^{*}$ \\
\hline \multirow[t]{4}{*}{7} & \multicolumn{8}{|c|}{ House environment has drainage or not water-logged } \\
\hline & No & $104(27.1 \%)$ & $280(72.9 \%)$ & & & & & \\
\hline & Yes & $63(17.5 \%)$ & $298(82.5 \%)$ & 1.757 & $\begin{array}{l}(1.235- \\
2.500)\end{array}$ & 9.926 & 1 & $0.002^{*}$ \\
\hline & Total & $167(22.4 \%)$ & $578(77.6 \%)$ & & & & & \\
\hline \multirow[t]{4}{*}{8} & \multicolumn{8}{|c|}{ Type of residential housing material } \\
\hline & Cement/Brick & $73(18.4 \%)$ & $324(81.6 \%)$ & & & & & \\
\hline & Mud, cornstalk etc & $94(27.0 \%)$ & $254(73.0 \%)$ & & & & & \\
\hline & Total & $167(22.4 \%)$ & $578(77.6 \%)$ & 0.609 & $\begin{array}{l}(0.430- \\
0.861)\end{array}$ & 7.930 & 1 & $0.005^{*}$ \\
\hline
\end{tabular}

\section{Conclusion}

This study concludes that negative WASH practices are associated with chronic malnutrition (stunting) and a combination of both chronic and acute malnutrition (underweight). Stunting was associated with all 8 WASH variables considered in this study, while underweight was associated with only 2 out of the 8 variables. The foregoing raises a germane concern about the role of WASH in malnutrition among school children and the need for a comprehensive and sustainable school feeding programme in the state and country at large. There is the need to also fully integrate WASH as a critical component of all nutrition intervention programmes. 


\section{Compliance with ethical standards}

\section{Acknowledgments}

The authors wishes to acknowledge the kind approval granted by the Gombe State Ministry of Health and the State Universal Basic Education Board (SUBEB). Also worthy of note are the unequivocal supports received from the various local education authority (LEA) of the six local governments visited for data collection. The different school managements' cooperation are also acknowledged as well as the participants' for volunteering to take in the study.

\section{Disclosure of conflict of interest}

All the authors declare that they have no conflict of interest.

\section{Statement of informed consent}

Informed consent was first obtained from the parents of the participants via the parent teachers association and managements of the schools that took part in this study. Additionally, a verbal consent was secured from each of the volunteering pupils, with the option of pulling out of the survey at any point he or she feels not disposed to continue.

\section{References}

[1] Development Initiatives. Global Nutrition Report (GNR): Shining a light to spur action on nutrition. Bristol, UK: Development Initiatives, 2017.

[2] Development Initiatives. 2018 Global Nutrition Report: Shining a light to spur action on nutrition. Bristol, UK: 2018 Development Initiatives.

[3] National Population Commission (NPC) [Nigeria] and ICF. Nigeria Demographic and Health Survey2018 Key Indicators Report. Abuja, Nigeria, and Rockville, Maryland, USA: 2019 NPC and ICF.

[4] UNICEF. The State of the World's Children 2019. Children, Food and Nutrition: Growing well in a changing world. 2019 UNICEF, New York.

[5] UNICEF / WHO / World Bank Group. Levels and trends in child malnutrition: key findings of the 2017 Edition of the Joint Child Malnutrition Estimates. Geneva: World Health Organization; 2017 Licence: CC BY-NC-SA 3.0 IGO.

[6] National Bureau of Statistics (NBS) and United Nations Children's Fund (UNICEF). Multiple Indicator Cluster Survey 2016-17, Survey Findings Report. Abuja, Nigeria: National Bureau of Statistics and United Nations Children's Fund.

[7] Akombi BJ, Agho KE, Hall JJ, Wali N, Renzaho A, \& Merom, D. Stunting, Wasting and Underweight in Sub-Saharan Africa: A Systematic Review. International journal of environmental research and public health, 2017; 14(8):863. doi:10.3390/ijerph14080863

[8] He Z, Bishwajit G, Zou D, Yaya S, Cheng Z, \& Zhou Y. Burden of Common Childhood Diseases in Relation to Improved Water, Sanitation, and Hygiene (WASH) among Nigerian Children. International journal of environmental research and public health, 2018; 15(6):1241. https://doi.org/10.3390/ijerph15061241.

[9] Hasanah I, \& Susanti H. Does water and sanitation effects on children's physical development? Evidence from Indonesia Family life Survey (IFLS) 2014. E3S Web of Conferences 2014; 74:09007. ICSoLCA. https://doi.org/10.1051/e3sconf/20187409007

[10] Brown J, Cairncross S, Ensink JH. Water, sanitation, hygiene and enteric infections in children. Arch Dis Child, 2013; 98(8):629-34.

[11] Crane RJ, Jones KD, Berkley JA. Environmental enteric dysfunction: an overview. Food Nutr Bull., $2015 ; 36$ (1_suppl1):S76-87.5.

[12] Van Cooten MH, Bilal SM, Gebremedhin S, Spigt M. The association between acute mal-nutrition and water, sanitation, and hygiene among children aged 6-59 months in rural Ethiopia. Matern Child Nutr. 2019; 15:e12631.https://doi.org/10.1111/mcn.126318of8 VAN COOTEN ET AL.bs_bs_banner.

[13] National Bureau of Statistics (NBS). Demographic Statistics Bulletin, 2017. https:// nigerianstat.gov.ng (Accessed on $23 / 07 / 2020$ ). 
[14] Gombe state bureau of statistics (GSBS). Personal visit to the state office/bureau in 2018. Data Supplied by the Chief Data Officer.

[15] Pocock SJ. Clinical Trials. A practical approach. New York: John Wiley and Sons, 1993.

[16] Jelliffe DB. The assessment of the nutritional status of the community. 1996 World Health Organisation, (WHO) Monograph series, No 53).

[17] WHO. WHO Multicentre Growth Reference Study Group. WHO child growth standards based on length/height, weight and age. Acta Paediatr Suppl; 2006; 450:76-85.

[18] National Population Commission (NPC) [Nigeria] and ICF. Nigeria Demographic and Health Survey 2018 Key Indicators Report, 2019. Abuja, Nigeria, and Rockville, Maryland, USA: NPC and ICF.

[19] Ogundele OM, Rapheal OM \& Abiodun AM. Effects of Municipal Waste Disposal Methods on Community Health in Ibadan - Nigeria. Polytechnica1, 2018; 61-72. doi:10.1007/s41050-018-0008-y

[20] Morakinyo OM, Adebowale AS, Obembe TA, Oloruntoba EO. Association between household environmental conditions and nutritional status of women of childbearing age in Nigeria. PLoS ONE, 2020; $15(12)$ : e0243356. https://doi.org/10.1371/journal.pone.0243356.

[21] Awel AA., Lema TB., \& Hebo HJ. Nutritional status and associated factors among primary school adolescents of pastoral and agro-pastoral communities, Mieso Woreda, Somali Region, Ethiopia: A comparative cross-sectional study. Journal of Public Health and Epidemiology, 2016; 8(11):297-310.

[22] Mshida HA, Kassim N, Mpolya E, Kimanya M. Water, sanitation, and hygiene practices associated with nutritional status of under-five children in semi-pastoral communities Tanzania. The American Journal of Tropical Medicine and Hygiene, 2018; 98(5):1242-1249. doi: 10.4269/ajtmh.17-0399.

[23] Ndukwu CI, Egbuonu I, Ulasi TO, Ebenebe JC. Determinants of undernutrition among primary school children residing in slum areas of a Nigerian city. Niger J Clin Pract., 2013; 16:178-83.

[24] Syed S, Duggan CP. Risk factors for malnutrition and environmental enteric dysfunction-you really are what you eat. J Pediatr; 2016; 178:7-8.

[25] Iqbal NT, Syed S, Sadiq K. et al. Study of Environmental Enteropathy and Malnutrition (SEEM) in Pakistan: protocols for biopsy based biomarker discovery and validation. BMC Pediatr 2019; 19:247 doi:10.1186/s12887019-1564-x

[26] Rahman S, Rahman A, Maniruzzaman M, \& Howlader M. Prevalence of undernutrition in Bangladeshi children. Journal of Biosocial Science, 2019; 52 (4):1-14. doi:10.1017/S0021932019000683

[27] Khan S, Zaheer S \& Safdar NF. Determinants of stunting, underweight and wasting among children < 5 years of age: evidence from 2012-2013 Pakistan demographic and health survey. BMC public health, 2019; $19(1): 358$. doi:10.1186/s12889-019-6688-2

[28] Unicef. The State of the World's Children, 1998. Access from https://www.unicef.org/sowc98/fig5.htm (Last date access, June 27, 2019)

\section{Author's short biography}

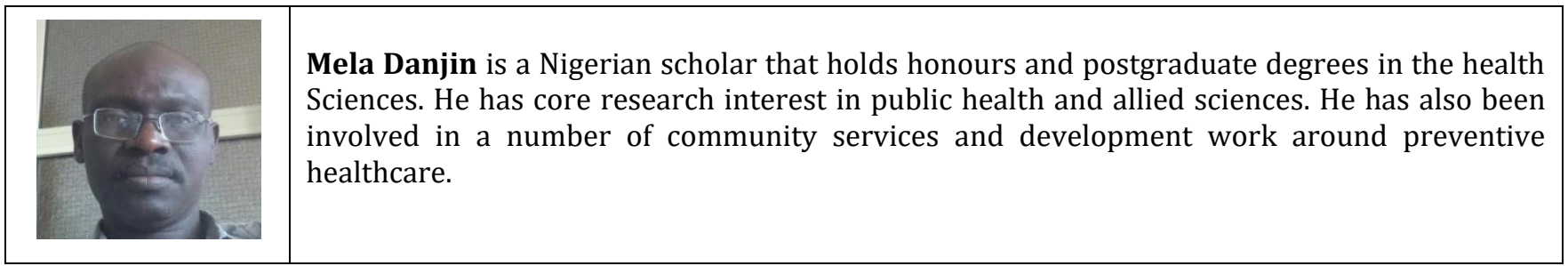

